LOCKMEED MARTIN

ENVIRONMENTAL RESTORATION PROGRAM
ORNL/ER-424
Data Management Implementation Plan for Interim Action at the Gunite and Associated Tanks, Oak Ridge National Laboratory, Oak Ridge, Tennessee
OSTI

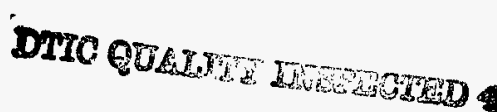

DISTAIBUTION OF THIS DOCUMENT IS UNLIMITED
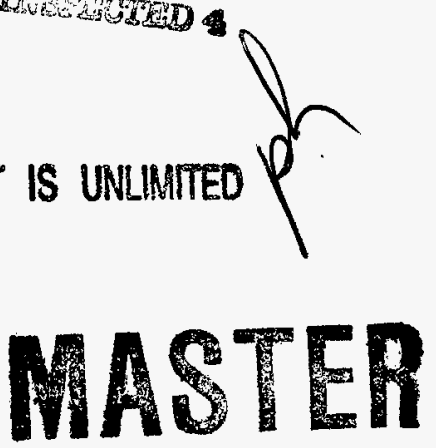

This document has been approved by the ORNL Technical Information Office for release to the public. Date: $3 / 24 / 98$

ENERGY SYSTEMS 


\section{DISCLAIMER}

This report was prepared as an account of work sponsored by an agency of the United States Government. Neither the United States Government nor any agency thereof, nor any of their employees, makes any wartanty, express or implied, or assumes any legal liability or responsibility for the accuracy, completeness, or usefulness of any information, apparatus, product, or process disclosed, or represents that its use would not infringe privately owned rights. Reference herein to any specific commercial product, process, or service by trade name, trademark, manufac. turer, or otherwise does not necessarily constitute or imply its endorsement, recommendation, or favoring by the United States Government or any agency thereof. The views and opinions of authors expressed herein do not necessarily state or reflect those of the United States Government or.any agency thereof. 


\title{
Data Management Implementation Plan for Interim Action at the Gunite and Associated Tanks, Oak Ridge National Laboratory, Oak Ridge, Tennessee
}

\author{
Date Issued-March 1998
}

\author{
Prepared for the \\ U.S. Department of Energy \\ Office of Environmental Management \\ under budget and reporting code EW 20 \\ Environmental Management Activities at the \\ OAK RIDGE NATIONAL LABORATORY \\ Oak Ridge, Tennessee 37831 \\ managed by \\ LOCKHEED MARTIN ENERGY SYSTEMS, INC. \\ for the \\ U.S. DEPARTMENT OF ENERGY \\ under contract DE-AC05-84OR21400
}


APPROVALS

Data Management Implementation Plan for Interim Action at the Gunite and Associated Tanks, Oak Ridge National Laboratory, Oak Ridge, Tennessee

(ORNL/ER-424)

March 1998

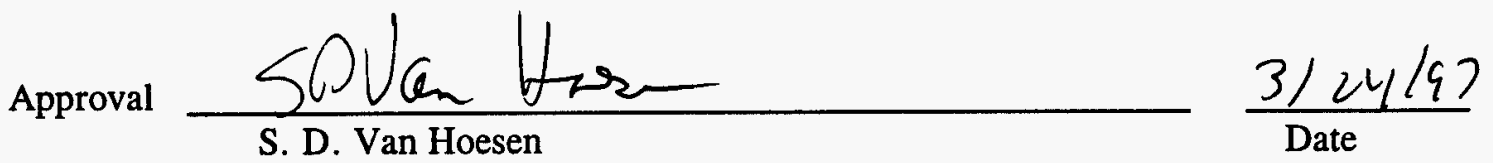
Project Manager

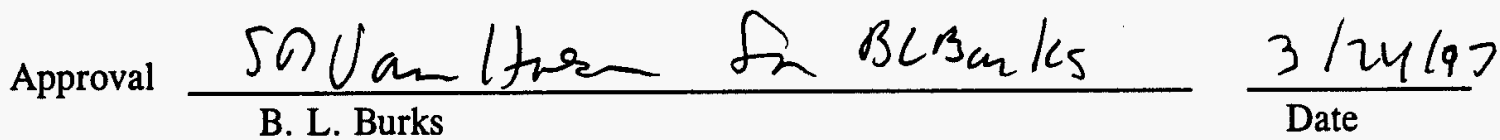
Waste Removal Operations Manager
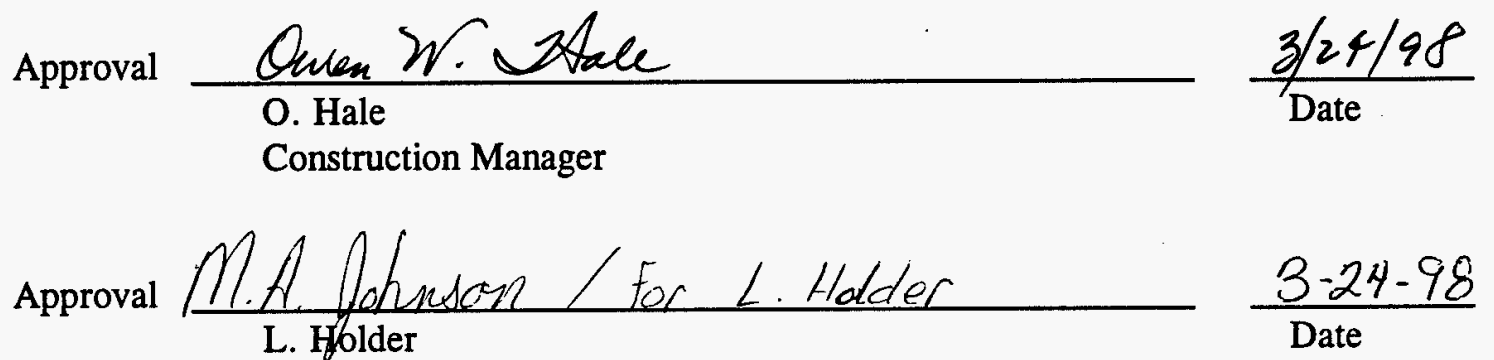

Facility Manager
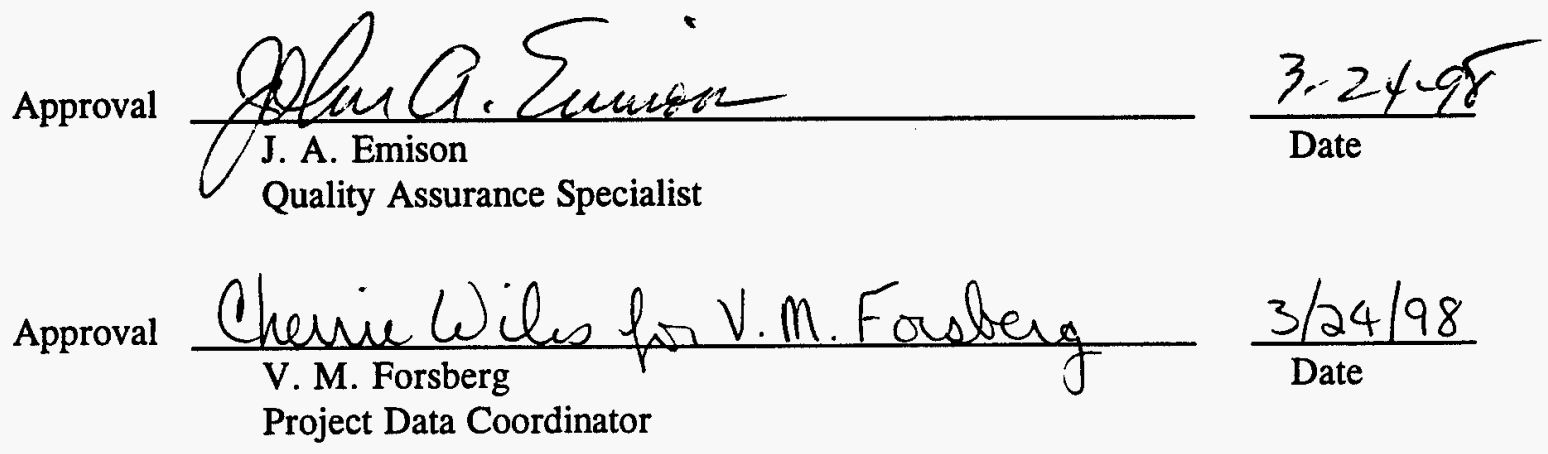


\section{PREFACE}

This document, Data Management Implementation Plan for Interim Action at the Gunite and Associated Tanks, Oak Ridge National Laboratory, Oak Ridge, Tennessee (ORNL/ER424), was developed under Work Breakdown Structure 1.12.06.20.01.02.12 for the Gunite and Associated Tanks Remediation Project. This document identifies the data needs and sources, roles and responsibilities, and data management activities associated with the project. 


\section{CONTENTS}

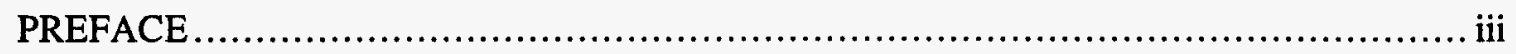

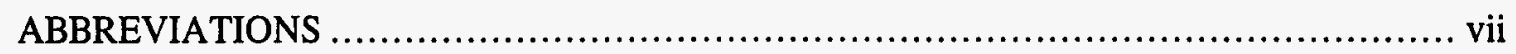

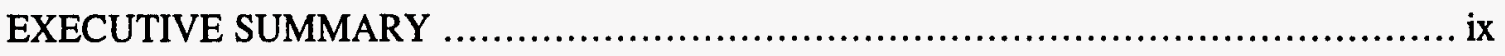

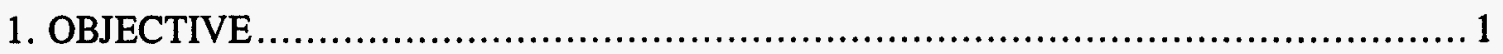

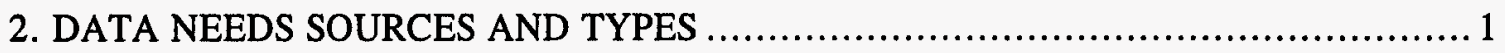

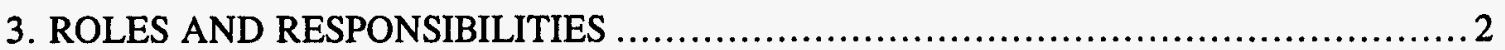

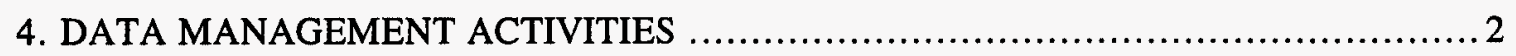

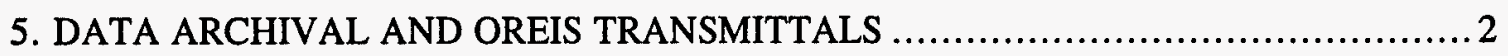




\section{ABBREVIATIONS}

CERCLA Comprehensive Environmental Response, Compensation, and Liability Act DOE U.S. Department of Energy

GAAT Gunite and Associated Tanks

OREIS Oak Ridge Environmental Information System

ORNL Oak Ridge National Laboratory 


\section{EXECUTIVE SUMMARY}

This Data Management Implementation Plan documents the data needs, sources, and types of data to be collected during the Gunite and Associated Tanks (GAAT) remediation operations. The data management roles and responsibilities are also identified for the project team members. Data archival and Oak Ridge Environmental Information System transmittals have also been identified. These activities are being conducted to support the Comprehensive Environmental Response, Compensation, and Liability Act Interim Remedial Action at the Gunite and Associated Tanks at Oak Ridge National Laboratory in Oak Ridge, Tennessee. The activities will be performed in concert with GAAT operations procedures and guidelines. 


\section{OBJECTIVE}

The Gunite and Associated Tanks (GAAT) Project is currently conducting a Comprehensive Environmental Response, Compensation, and Liability Act (CERCLA) Interim Remedial Action to reduce uncertainties on the potential cost and effectiveness of remote tank cleaning equipment being produced jointly between the U.S. Department of Energy (DOE); Oak Ridge National Laboratory (ORNL); Lockheed Martin Energy Systems, Inc.; and associated subcontractors with the DOE EM-50 Program. The goal of this document is to ensure that all procedures have been followed to provide reliable, verifiable data that are technically defensible. The data collected will be used to support closure of the tanks, compare the expected versus actual waste volume and curies to aid in conducting operations, and verify the performance of developmental equipment.

\section{DATA NEEDS SOURCES AND TYPES}

This study will identify data to be issued to the Oak Ridge Environmental Information System (OREIS) for use in the decision-making process of the Record of Decision for the closure of GAAT at ORNL. The data obtained for transfer into OREIS will be from the analytical results performed on samples gathered using a Bristol Isolock slurry sampler, a wall-coring device, and other sampling means, as required. The sampling is to be performed during the GAAT operations for Tanks W-3 through W-10. A listing of required analyses is provided in the following documents:

-North Tank Farm In-Process Analysis Program (IPAP) for the Isolock Sampler at the Gunite and Associated Tanks at Oak Ridge National Laboratory, Oak Ridge, Tennessee, and

-Sampling and Analysis Plan for the Gunite and Associated Tanks Interim Remedial Action, Wall Coring and Scraping, Oak Ridge National Laboratory, Oak Ridge, Tennessee (ORNL/ER-412/R1).

Miscellaneous samples of tank supernate, wall scrapings, and tank sludge are intended for engineering process knowledge and will not be submitted to OREIS. The laboratory results of the miscellaneous samples will be documented in the final analytical results report and in the project files.

Lab results for wall and sludge samples that will be used as part of CERCLA final closure decision process will be submitted to OREIS. 


\section{ROLES AND RESPONSIBILITIES}

Overall roles and responsibilities for this work are defined in the Gunite and Associated Tanks Project Plan, December 19, 1996, ITO-FY97-048. The Project Management Team consists of the following:

- Project Manager, Chairman: S. D. Van Hoesen

- Site Development and Closure Operations Manager: Owen Hale

- Technical Manager: Marshall Johnson

- Health and Safety Manager: Paul Abston

- Facility Manager: Lou Holder

- Construction Manager: Owen Hale

- Environmental Compliance Manager: Denise Reynolds

- Waste Removal Operations Manager: Barry Burks

- Business Manager: Ray Riner

- Quality Assurance: John Emison

- Sampling Manager: Cherrie Wiles

- Project Data Coordinator: Virginia M. Forsberg

The data collection sources are listed in Lockheed Martin Energy Systems, Inc., Gunite and Associated Tanks Treatability Studies Operations Project Records Plan (GAAT-TS/P-301).

\section{DATA MANAGEMENT ACTIVITIES}

The data quality objectives, basis for sampling, sample collection activities, summary of the analysis for each functional area, data to be collected during operations, and analytical methods to be used during analysis of samples are documented in the In-Process Analysis Program and ORNL/ER-412/R1, referred to in Sect. 2. These documents describe the analysis scheme analysis procedures and quality control for samples. Data verification and validation must be reported for all data submitted to OREIS.

\section{DATA ARCHIVAL AND OREIS TRANSMITTALS}

Reports of the validated results from all samples taken during the GAAT Interim Remedial Action will be issued after all analysis of sampling has been completed. These summary reports of analytical results will contain the isolock slurry, wall coring, and miscellaneous sample results. The reports will be issued, and the results for only the isolock slurry, wall coring, and sludge samples which are used as part of the CERCLA final closure decision-making process will be submitted into OREIS by the Project Data Coordinator. The miscellaneous data were used as process knowledge for operations in the South Tank Farm and are not intended for 
submittal for tank closure decision-making purposes. Copies of the supporting field measurements, chain of custody form, laboratory results, field log book pages, and geographic coordinates for the sample will be submitted to the GAAT project working files and/or the Environmental Management and Enrichment Facilities Document Management Center in accordance with the Operations Project Records Plan (GAAT-RP/P-301).

A document clearance form will be submitted for documents containing data that are entered into OREIS. 


\section{DISTRIBUTION}

1. B. L. Burks

2. J. M. Forsberg

3. O. Hale

4. L. Holder

5. L. B. Raulston

6. S. D. Van Hoesen

7. Central Research Library

8. File-EMEF DMC-RC

9. C. O. Wiles, The Providence Group, Inc., P.O. Box 23408, Knoxville, TN 37933-1408

10. J. A. Emison, XL Associates, Inc., 677 Emory Valley Road, Oak Ridge, TN 37830 


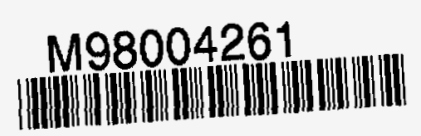

Report Number (14) ORNL/ER--424

Publ. Date (11) 199803
Sponsor Code (18)
UC Category (19) UC-902, DOE/ER 
Please do not forward or discard this document.

If this address is not correct for the designated addressee, please return this document to the

EMEF Document Management Center Building K-1002, MS 7243

Lockheed Martin Energy Systems, Inc.

P.O. Box 2003

Oak Ridge, TN 37831 